\title{
A study on association of virulence determinants of verotoxic Escherichia coli isolated from cattle calves
}

\author{
Singh Parul' ${ }^{1}$ Basanti Bist² ${ }^{2}$ Barkha Sharma ${ }^{3}$, Udit Jain² and Janardan K. Yadav²
}

1. State Veterinary Hospital, Dhanateja, Mathura, Uttar Pradesh, India; 2. Department of Veterinary Public Health, College of Veterinary Sciences and Animal Husbandry, UP Pandit Deen Dayal Upadhyaya Veterinary Science University, Mathura, Uttar Pradesh, India; 3. Department of Epidemiology and Preventive Veterinary Medicine, College of Veterinary Sciences and Animal Husbandry, UP Pandit Deen Dayal Upadhyaya Veterinary Science University, Mathura, Uttar Pradesh, India.

Corresponding author: Singh Parul, e-mail: parulkaler@rediffmail.com, BB: vasanti.bist@gmail.com, BS: manubarkha@yahoo.com,UJ: druditjain@hotmail.com, JKY: janardanyadav1987@gmail.com

Received: 06-05-2016, Accepted: 25-07-2016, Published online: 29-08-2016

doi: 10.14202/vetworld.2016.915-918 How to cite this article: Parul S, Bist B, Sharma B, Jain U, Yadav JK (2016) A study on association of virulence determinants of verotoxic Escherichia coli isolated from cattle calves, Veterinary World, 9(8): 915-918.

Abstract

Aim: The present study was conducted to find the association among virulence determinants of verotoxic Escherichia coli (VTEC) isolated from cattle calf feces.

Materials and Methods: A total of 216 cattle calf fecal samples were collected aseptically and processed under required conditions for the isolation of $E$. coli . The isolates were further subjected to multiplex polymerase chain reaction (mPCR) for the detection of virulent genes. All the VTEC isolates were serotyped at the Central Research Institute, Kasauli, Himachal Pradesh. The VTEC isolates were observed for the enterohemolysin production on washed sheep blood agar (wSBA).

Results: A total of 177 presumptive $E$. coli were isolated from 216 calf fecal samples revealing an overall prevalence of E. coli to be $81.94 \%$. A total of $32(14.81 \%)$ isolates were detected as VTEC through mPCR. The prevalence of verotoxin genes $v t 1, v t 2$, and combination of $v t 1+v t 2$ in the VTEC isolates was found to be $12(37.5 \%), 14(43.75 \%)$, and $6(18.75 \%)$, respectively. Other virulent genes eaeA and $h l y \mathrm{~A}$ were found in 6 and 11 VTEC strains with prevalence values of $18.75 \%$ and $34.37 \%$, respectively. A total of 13 different $\mathrm{O}$ serogroups were revealed in serotyping of 32 VTEC isolates. Out of 32 VTEC strains, only $26(81.25 \%)$ were enterohemolytic on wSBA as they produced the characteristic small, turbid zone of hemolysis around the streaking line. Although enterohemolysin production has been attributed to the presence of $h l y \mathrm{~A}$ gene, only 11 of 26 enterohemolysin producing VTEC were found to be harboring the hlyA gene (11/26) 42.03\%.

Conclusion: The present study concludes that there might be an association between the presence of verotoxin genes and enterohemolysin production in VTEC group of E. coli.

Keywords: enterohemolysin gene (hlyA), enterohemolysin toxin, intimin gene (eaeA), verotoxic Escherichia coli, verotoxin genes ( $v t 1$ and $v t 2)$, virulence determinants.

\section{Introduction}

The emergence of verotoxin-producing Escherichia coli (VTEC) is one of the biggest challenges for food safety and cattle industry worldwide [1]. The VTEC are also known as Shiga toxin-producing $E$. coli and are responsible for producing a spectrum of illness in humans including diarrhea, hemorrhagic colitis, hemolytic uremic syndrome (HUS), and thrombotic thrombocytopenic purpura [2,3]. Most of the VTEC associated foodborne infections in humans are supposed to be consumption of foods (undercooked ground beef, unpasteurized dairy products, and vegetables) and water contaminated with ruminant feces and other environmental sources [4,5].

\footnotetext{
Copyright: Parul, et al. Open Access. This article is distributed under the terms of the Creative Commons Attribution 4.0 International License (http://creativecommons.org/licenses/by/4.0/), which permits unrestricted use, distribution, and reproduction in any medium, provided you give appropriate credit to the original author(s) and the source, provide a link to the Creative Commons license, and indicate if changes were made. The Creative Commons Public Domain Dedication waiver (http://creativecommons.org/ publicdomain/zero/1.0/) applies to the data made available in this article, unless otherwise stated.
}

The ruminants are established natural reservoirs of VTEC, carrying it asymptomatically in their intestine and excreting in feces [6]. The prevalence of the VTEC in the cattle feces is generally reported to be high especially in calves [7,8]. More than $400 \mathrm{O}: \mathrm{H}$ serotypes of VTEC have been isolated from cattle and humans while over 100 serotypes are found to be linked with human diseases $[9,10]$. The pathogenicity of VTEC is attributed to a number of virulence factors, including potent verotoxins (VT1 and VT2, encoded by phage-mediated genes $v t 1$ and $v t 2$ ), an intimin protein associated with attaching and effacing lesions (encoded by eaeA gene) and enterohemolysin, a lytic toxin (encoded by hlyA gene) [11-13]. Several studies have indicated the association between these virulence factors such as vts, hlyA genes, and enterohemolysin production in VTEC serotypes originating from varied sources $[14,15]$, but more research is needed to prove their association.

Thus, this study aims to find the association in virulence determinants of VTEC isolated from cattle calf feces. 


\section{Materials and Methods}

\section{Ethical approval}

For this study faecal samples were collected from immediately voided faeces of animals. So this work does not require any ethical approval.

\section{Sampling, enrichment, and phenotypic characteriza- tion of isolates}

A total of 216 fecal samples of cattle calves (below 1 year) were collected from three organized dairy farms of Uttar Pradesh state, from June 2012 to May 2013. All the samples were transported under chilled conditions and processed immediately in the laboratory for the better recovery of $E$. coli. The $1 \mathrm{~g}$ of feces was enriched in $10 \mathrm{ml}$ of trypticase soya broth (HiMedia, India) containing acriflavine $(10 \mathrm{mg} / \mathrm{L})$ and incubated at $37^{\circ} \mathrm{C}$ for $24 \mathrm{~h}$ [16]. The enriched inoculum was streaked on MacConkey agar and the resulting lactose fermenting pink, smooth, and round colonies were further streaked on the selective eosin methylene blue (EMB) agar (HiMedia, India) and incubated at $37^{\circ} \mathrm{C}$ for $24 \mathrm{~h}$. The colonies showing green metallic sheen on EMB agar were picked as presumptive $E$. coli and streaked on nutrient agar slants and biochemically confirmed by kit (KB010 Hi E. coli Identification kit-HiMedia, India).

\section{Virulence detection}

A multiplex polymerase chain reaction (mPCR) was carried out using four sets of oligonucleotide primers for detection of virulent genes $v t 1, v t 2$, eaeA, and hlyA [17]. The template DNA was extracted from a single colony of each isolate using kit (Genei, Bengaluru). The purity and concentration of extracted DNA were detected by nanodrop method (Eppendorf, German). The every $25 \mu \mathrm{l}$ PCR reaction mixture of contained $\times 1$ PCR buffer, $1.5 \mathrm{mM} \mathrm{MgCl}$, each primer at a concentration of $40 \mathrm{nM}, 200 \mu \mathrm{M}$ each of deoxynucleotide triphosphates, one unit of Taq DNA polymerase, and $2.0 \mu \mathrm{l}$ of template DNA. The PCR reaction was performed in a thermal cycler (Cyber Lab, India) using standard cycling conditions and amplified products were separated by electrophoresis on $2 \%$ agarose gel and visualized with ethidium bromide. Standard 100 bp DNA ladder (Genei, Bengaluru) was used as marker.

\section{Serotyping and detection of enterohemolysin (E-hly) toxin}

All the isolates that turned out to be positive through mPCR method were also serotyped at the National Salmonella and Escherichia Center, Central Research Institute, Kasauli, Himachal Pradesh, India.

Enterohemolysin production in VTEC isolates was observed as per the method of Beutin et al. [18]. All the isolated VTEC were streaked over 5\% washed sheep blood agar (wSBA) plates supplemented with $10 \mathrm{mM}$ calcium chloride incubated at $37^{\circ} \mathrm{C}$ and examined at $18 \mathrm{~h}$. The VTEC isolates producing small turbid hemolytic zone around the streaking line after $18 \mathrm{~h}$ were considered as enterohemolytic.

\section{Results}

\section{Phenotypic characterization of VTEC}

A total of 177 presumptive $E$. coli were isolated from 216 fecal samples revealing a total prevalence of $81.94 \%$. These isolates showed pink-colored smooth colonies on MLA and produced distinct, clear greenish metallic sheen over EMB. All the isolates showing following biochemical reactions as negative for Voges-Proskauer, hydrogen sulfide, citrate, oxidase and urease production, and positive for indole and methyl red tests were biochemically confirmed as E. coli.

\section{Detection of virulent genes}

A total of $32 \mathrm{E}$. coli isolates from calf feces found to be positive for virulent genes ( $v t 1, v t 2$, eaeA, and hlyA) by mPCR showing a prevalence of $14.8 \%$. The virulent genes were present either singly or in combinations, showing a prevalence of $v t 1, v t 2$, and $(v t 1+v t 2)$ genes as $12(37.5 \%), 14(43.75 \%)$, and $6(18.75 \%)$, respectively. Other virulent genes eaeA and hlyA were present in 6 and 11 VTEC strains showing prevalence values $18.75 \%$ and $34.37 \%$, respectively (Table-1).

\section{Serotyping}

A total of 13 different $\mathrm{O}$ serogroups were revealed on serotyping of 32 VTEC isolates (Table-1). Of these serotypes, four were identified as O9, O26, O91, and O156, which have been shown to be associated with HUS in human being.

\section{Detection of enterohemolysin (E-h/y) in VTEC}

In the hemolysis assay, out of 32 VTEC isolates, $26(81.25 \%)$ showed the enterohemolysin production on wSBA as they produced small, turbid zone of hemolysis around the streaking line. All the 26 enterohemolytic VTEC isolates revealed with verotoxin genes as $12(46.5 \%)$ had $v t 1$ gene, $8(30.76 \%)$ isolates harbored $v t 2$ gene, and $6(23.07 \%)$ isolates had both the genes $(v t 1+v t 2)$. Although enterohemolysin production has been attributed the presence of hlyA gene, only 11 of 26 enterohemolysin producing VTEC were found to be harboring the hlyA gene 11 (42.03\%).

\section{Discussion}

In the present study, the prevalence of E. coli in the feces of cattle calves was $81.94 \%$. The prevalence value of current study had nearly coincided with the findings of other countries as in Iran (86.7\%) [19], Egypt (75.6\%) [20], and India (75\%) [21], whereas the lower prevalence was reported in Egypt (63.6\%) [22].

During the study, $14.81 \% \mathrm{E}$. coli isolates were found as VTEC through MPCR in the calves feces. The serotyping results of the current study depicted that all the VTEC isolates were belonged to the nonO157 VTEC group. The wide range of prevalence values of non-O157 VTEC (0.42 to $74 \%)$ and $E$. coli O157:H7 (0.2 to $48.8 \%)$ has been reported from cattle feces worldwide [23]. The prevalence of VTEC reported in our study lies within globally reported a range of VTEC from cattle feces. Almost similar 
Table-1: Distribution of virulent genes ( $v t 1, v t 2$, eaeA, and $h l y \mathrm{~A})$ and enterohemolysin production in VTEC isolates from cattle calves feces.

\begin{tabular}{|c|c|c|c|c|c|c|c|}
\hline Serotypes & Number of VTEC isolates & $v t 1$ & $v t 2$ & $v t 1+v t 2$ & eaeA & hlyA & Enterohemolysin production \\
\hline 09 & 4 & - & - & + & - & + & + \\
\hline 011 & 5 & + & - & - & - & + & + \\
\hline 026 & 1 & + & - & - & + & - & + \\
\hline $\mathrm{O} 27$ & 2 & - & + & - & - & - & + \\
\hline O34 & 2 & - & + & - & - & - & - \\
\hline 052 & 4 & - & + & - & - & - & - \\
\hline 056 & 3 & - & + & - & - & - & + \\
\hline 081 & 3 & + & - & - & + & - & + \\
\hline 083 & 2 & + & - & - & - & - & + \\
\hline 084 & 1 & - & + & - & - & - & + \\
\hline 091 & 1 & + & - & - & + & - & + \\
\hline 0134 & 2 & - & + & - & - & - & + \\
\hline 0156 & 2 & - & - & + & + & + & + \\
\hline
\end{tabular}

VTEC $=$ Verotoxic Escherichia coli

prevalence of VTEC has been reported in another study from India by Mishra et al. 13.4\% [24] while higher prevalence values have been reported from other places such as Egypt (26.7\%) [25], California $(37.9 \%)$ [26], Ireland (40\%) [27], and Florida (58.1\%) [6]. The wide variations in prevalence values of $E$. coli and VTEC in calves feces can be attributed to epidemiological determinants such as stocking density, age, sex, and season, whereas sampling strategy, sample handling, and laboratory methods might also have profound effect on prevalence values reported in different countries $[28,29]$.

The enterohemolysin is a lytic toxin which is encoded by a large virulence plasmid and was initially supposed to be produced by VTEC group of E. coli. The association of enterohemolysin production and VTEC group of E. coli was first identified by Beutin et al. [18] and later on this correlation was reported by numerous other research workers. In this investigation, the prevalence of enterohemolysin production was $26(81.25 \%)$ which is almost similar to $89.9 \%$ reported by Rathore et al. [30] from cattle feces. In various other studies, prevalence values of enterohemolysin production by VTEC isolated from feces and other sources have been found as $31.18 \%$ [15], $68.29 \%$ [31], 86\% [14], and 97.6\% [32].

In few studies, a genomic relation has been studied with the production of enterohemolysin toxin in VTEC group of E. coli. In a study by Meng et al. [33], all 120 E. coli $\mathrm{O} 157: \mathrm{H} 7$ isolates harboring verotoxin genes produced the enterohemolysin. In another report, all the $E$. coli $\mathrm{O} 157$ isolates were found positive for hlyA gene and enterohemolytic phenotype [34]. In spite of the association of enterohemolysin production with $h l y$ A gene, the verotoxin gene $v t l$ was also found evident in enterohemolysin production in non-O157 VTEC isolates [15]. In the current study, the 26 nonO157 VTEC isolates were enterohemolytic on wSBA and only 11 VTEC isolates $(40.03 \%)$ were revealed the presence of $h l y \mathrm{~A}$ gene while the rest of isolates were harbored either $v t 1, v t 2$, or both $(v t 1+v t 2)$ the verotoxin genes but still produced this toxin on wSBA
(Table-1). It enforces the fact that the mere presence of $h l y \mathrm{~A}$ gene might not be the sole factor for the production of enterohemolysin, but the presence of verotoxin genes (either $v t 1, v t 2$, or both) also might favor its production of enterohemolysin thereby enhance the virulence of VTEC. The present study concludes that there might be an association between the presence of verotoxin genes and enterohemolysin production in VTEC group of E. coli.

\section{Conclusion}

The zoonotic agent VTEC contaminates the food chain and constitutes the major public health hazard. It is necessary to know all possible virulence factors for its control. The present study concludes that there might be an association between the presence of verotoxin genes and enterohemolysin production in VTEC group of E. coli. There is further need to study more on virulence factors of VTEC.

\section{Authors' Contributions}

SP, BB, BS, UJ, and JKY executed the study design and analyzed the data. SP performed the entire study under the guidance of BB. SP drafted and revised the manuscript with the help of BS and UJ. All authors read and approved the final manuscript.

\section{Acknowledgments}

The authors wish to express their heartfelt thanks to the Indian Council of Agricultural Research, New Delhi, India, for providing funds and necessary facilities through the project entitled "Outreach research programme on zoonotic diseases on vero cytotoxic" to carry out part of the research work.

\section{Competing Interests}

The authors declare that they have no competing interests.

\section{References}

1. Callaway, T.R., Edrington, T.S., Loneragan, G.H., Carr, M.A. and Nisbet, D.J. (2013) Shiga toxin producing Escherichia coli (STEC) ecology in cattle and management 
based options for reducing fecal shedding. Agric. Food Anal. Bacteriol., 3: 39-69.

2. Beraldo, L.G., Borges, C.A., Maluta, R.P., Cardozo, M.V., Rigobelo, E.C. and A'vila, F.A. (2014) Detection of Shiga toxigenic (STEC) and enteropathogenic (EPEC) Escherichia coli in dairy buffalo. Vet. Microbiol., 170: 162-166.

3. Parul, B.B., Sharma, B. and Jain, U. (2014) Virulence associated factors and antibiotic sensitivity pattern of Escherichia coli isolated from cattle and soil. Vet. World, 7(5): 369-372.

4. Bonardi, S., Alpigiani, I., Tozzoli, R., Vismarra, A., Zecca, V., Greppi, C., Bacci, C., Bruini, I. and Brindani, F. (2015) Shiga toxin-producing Escherichia coli O157, O26 and $\mathrm{O} 111$ in cattle faeces and hides in Italy. Vet. Rec. Open., 2(1): e000061. DOI: 10.1136/vetreco-2014-000061.

5. Duffy, G., Burgess, C.M. and Bolton, D.J. (2014) A review of factors that affect the transmission and survival of verocytotoxigenic Escherichia coli in the European farm to fork chain. Meat Sci., 97: 375-383.

6. Mir, R.A., Weppelmann, T.A., Kang, M., Bliss, T.M., DiLorenzo, N., Lamb, G.C., Ahn, S. and Jeong, K.C. (2015) Association between animal age and the prevalence of Shiga toxin-producing Escherichia coli in a cohort of beef cattle. Vet. Microbiol., 175: 325-331.

7. Dastmalchi, S.H. and Ayremlou, N. (2012) Characterization of Shiga toxin-producing Escherichia coli (STEC) in faeces of healthy and diarrheic calves in Urmia region. Iran. J. Microbiol., 4(2): 63-69.

8. Islam, M.Z., Musekiwa, A., Islam, K., Ahmed, S., Chowdhury, S. and Ahad, A. (2014) Regional variation in the prevalence of E. coli $\mathrm{O} 157$ in cattle: A meta-analysis and meta-regression. PLoS One, 9(4): e93299. DOI: 10.1371/ journal.pone.0093299.

9. Karma, M.R., Jhonson, P., McEwen, A. and Gyles, L. (2008) Prevalence and characterization of verotoxin producing Escherichia coli (VTEC) in cattle from an Ontario abattoir. Can. J. Vet. Res., 72(4): 297-302.

10. Hernandez, R.G., McMullen, L. and Gänzle, M.G. (2015) Development and validation of a surrogate strain cocktail to evaluate bactericidal effects of pressure on verotoxigenic Escherichia coli. Int. J. Food Microbiol., 205: 16-22.

11. Thomas, K.M., McCann, M.S., Collery, M.M., Logan, A., Whyte, P., McDowell, D.A. and Duffy, G. (2012) Tracking verocytotoxigenic Escherichia coli O157, O26, O111, $\mathrm{O} 103$ and $\mathrm{O} 145$ in Irish cattle. Int. J. Food. Microbiol., 153: 288-296.

12. Bosilevac, J.M. and Koohmaraie, M. (2011) Prevalence and characterization of non O157 Shiga toxin-producing Escherichia coli isolates from commercial ground beef in the United States. Appl. Environ. Microbiol., 77: 2103-2112.

13. Sinha, N., Kshirsagar, D.P., Brahmbhatt, M.N. and Nayak, J.B. (2015) Detection and virulence gene characterization of Shiga toxigenic $E$. coli from buffalo meat samples. Indian J. Anim. Res., 49(5): 694-698.

14. Hazarika, R.A., Singh, D.K., Kapoor, K.N., Agrawal, R.K., Pandey, A.B. and Rajkumar, D.N. (2004) Detection and charecterization of verotoxin -producing Escherichia coli (VTEC) isolated from buffalo meat. J. Food Saf., 24: 281-290.

15. Bhong, C.D., Brahmbhatt, M.N., Joshi, C.G. and Rank, D.N. (2008) Detection of virulence determinants by real time PCR in E. coli isolated from mutton. Meat Sci., 80: 1129-1131.

16. Edward, P.R. and Ewing, W.H. (1972) Identification of Enterobacteriaceae. Burgess Publishing Company, Minnesota, USA.

17. Paton, J.C. and Paton, A.W. (1998) Pathogenesis and diagnosis of Shiga-toxin producing Escherichia coli infections. Clin. Microbiol. Rev., 11: 450-479.

18. Beutin, L., Montenegro, M.A., Orskov, I., Orskov, F.,
Prada, J., Zimmermann, S. and Stephan, R. (1989) Close association of verotoxin (Shiga-like toxin) production with enterohaemolysin production in strains of Escherichia coli. J. Clin. Microbiol., 27: 2559-2564.

19. Pourtaghi, H., Dahpahlavan, V. and Momtaz, H. (2013) Virulence genes in Escherichia coli isolated from calves with diarrhoea in Iran. Comp. Clin. Pathol., 22: 513-515.

20. El-Seedy, F.R., Abed, A.H., Yanni, H.A. and El-Rahman, S.A.A. (2016) Prevalence of Salmonella and E. coli in neonatal diarrheic calves. J. Basic Appl. Sci., 5: 45-51.

21. Hemashenpagam, N., Kiruthiga, B., Selvaraj, T. and Panneerselvam, A. (2009) Isolation, identification and characterization of bacterial pathogens causing calf diarrhoea with special reference to Escherichia coli. Int. J. Microbiol., $7(2): 1-4$.

22. Osman, K.M., Mustafa, A.M., Elhariri, M. and Abdelhamed, G.S. (2013) The distribution of Escherichia coli serovars, virulence genes, gene association and combinations and virulence genes encoding serotypes in pathogenic $E$. coli recovered from diarrhoeic calves, sheep and goat. Trans. Emerg. Dis., 60(1): 69-78.

23. Hussein, H.S. and Sakuma, T. (2005) Prevalence of Shiga toxin-producing Escherichia coli in dairy cattle and their products. J. Dairy Sci., 88: 450-465.

24. Mishra, R.P., Jain, U., Bist, B., Verma, A.K. and Kumar, A. (2016) prevalence of verotoxic Escherichia coli in faecal samples of domestic as well as wild ruminants in Mathura district and Kanpur zoo. Vet. World, 9(1): 71-74.

25. Ghoneim, N.H., Abdel-Moein, K.A. and Mohamed, M.A. (2014) Are non-O157 Shiga toxin-producing Escherichia coli imposing their predominance over $\mathrm{O} 157$ in farm animals and human? Glob. Vet., 12(5): 636-642.

26. Cooley, M.B., Jay-Russell, M., Atwill, E.R., Carychao, D., Nguyen, K. and Quiñones, B. (2013) Development of a robust method for isolation of Shiga toxin-positive Escherichia coli (STEC) from fecal, plant, soil and water samples from a leafy greens production region in California. PLoS One, 8: e65716. DOI: 10.1371/journal.pone.0065716.

27. Monaghan, A., Byrne, B., Fanning, S., Sweeney, T., McDowell, D. and Bolton, D.J. (2011) Serotypes and virulence profiles of non-O157 Shiga toxin-producing Escherichia coli isolates from bovine farms. Appl. Environ. Microbiol., 77(24): 8662-8668.

28. Amézquita-López, B.A., Quiñones, L.B.G. and Chaidez, C. (2014) Virulence profiling of Shiga toxin-producing Escherichia coli recovered from domestic farm animals in North Western Mexico. Front. Cell. Infect. Microbiol., DOI: 10.3389/fcimb.2014.00007.

29. Cho, Y. and Yoon, K.J. (2014) An overview of calf diarrhea-infectious etiology, diagnosis, and intervention. J. Vet. Sci., 15(1): 1-17.

30. Rathore, R.S., Bachhil, V.N, Agarwal, R.K. and Kapoor, K.N. (2002) Enterohaemolysin production: An important screening test for detection of verotoxic Escherichia coli. Indian J. Comp. Microbiol. Immunol. Infect. Dis., 23: 197-198.

31. Banerjee, R., Kapoor, K.N., Agrawal, R.K. and Gbatak, S. (2001) Verotoxin producing Escherichia coli (VTEC) in foods of animal origin. J. Food Sci. Technol., 38: 82-84.

32. Bettelheim, K.A. (1995) Identification of enterohaemorrhagic Escherichia coli by means of their production of enterohemolysin. J. Appl. Bacteriol., 79: 178-180.

33. Meng, J., Jaho, S. and Doyle, M.P. (1998) virulence genes of Shiga toxin producing Escherichia coli isolated from food, animals and humans. Int. J. Food Microbiol., 45: 229-235.

34. Aslantas, O., Erdogan, S., Cantekin, Z., Gulacti, I., Gulsum, A. and Evrendilek. (2006) Isolation and characterization of verocytotoxin-producing Escherichia coli $\mathrm{O} 157$ from Turkish cattle. Int. J. Food Microbiol., 106: 338-342. 